\title{
СТАНОВЛЕННЯ ТА ШЛЯХИ УДОСКОНАЛЕННЯ ОБЛІКУ КРИПТОВАЛЮТ
}

\section{Ковальова Т.В. канд. екон. наук, доцент \\ Харківський національний автомобільно-дорожній університет}

Постановка проблеми та їі зв'язок із практичними завданнями. Поширення IT-технологій і загальна комп'ютеризація, впливаючи на фінансові системи окремих країн та інші сторони економіки, сприяють появі нових фінансових інститутів, інструментів та форм взаємодії між людьми. Такою фінансовою новацією стала криптовалюта. Уперше термін «криптовалюта» почали використовувати 3 появою платіжної системи «Bitcoin», яка була розроблена у 2009 році особою або групою осіб під псевдонімом Сатосі Накамото [1]. Бухгалтерський облік не може стояти осторонь від цього об'єкту, оскільки, саме він формує повну та достовірну інформацію про діяльність підприємства. Однак, облікові аспекти криптовалют є досі невизначними i потребують подальшого дослідження.

Аналіз останніх досліджень i публікацій. Фінансовий істеблішмент поступово офіційно визнає криптовалюти i, відповідно, набуває нового змісту економічна наука. Ця проблематика все сильніше актуалізується у працях українських вчених. Низка вчених, серед яких, Ярова К., Волосович С. розкриваючи сутність поняття «криптовалюта», розглядали основні відмінності між електронними грошима і віртуальною валютою та досліджували досвід регулювання криптовалют у зарубіжних країнах $[2,3]$. Шевченко Л., вивчаючи сутність та порядок відображення в обліку операцій 3 криптоактивами, запропоновувала здійснювати його за допомогою міжнародних стандартів фінансової звітності [4]. Інші автори [5-8] проблему відображення в обліку криптовалют досліджували через їх економічну сутність. Незважаючи на їх напрацювання, питання коректного відображення криптовалют у обліку залишається відкритим і потребує вирішення.

Невирішені складові загальної проблеми. В Україні, як і загалом у світі, залишаються невирішеними низка питань щодо проведення операцій 3 віртуальними валютами, а саме: невизначеність їх правового статусу; відсутність методики обліку операцій 3 ними; неврегульованість бази оподаткування.

Формулювання цілей статі. Метою статті $є$ висвітлення існуючих точок зору щодо обліку криптовалют і розробка практично значимих пропозицій його покращення.

Виклад основного матеріалу дослідження. Одностайної думки 3 приводу відображення в обліку криптовалют немає, тому що вітчизняні науковці по-різному трактують криптовалюту. О. Петрук прирівнює криптовалюту до довгострокових фінансових інвестицій непов'язаним сторонам або поточних фінансових інвестицій в залежності від цілей придбання $[5$, с. 52 - 
53]. Т. Яцик пропонує розглядати криптовалюту як особливий електронний платіжний засіб, курс якого підтримується тільки попитом і пропозицією, тобто розглядає криптовалюту як різновид електронних грошей [6, с. 349-354]. О. Загнітко вважає, що криптовалюта в Україні може визначатися різними шляхами як «актив», «товар» чи «послуга» [7]. А. Кувшинова та К. Безверхий взагалі спростували визначення економічної сутності криптовалюти як грошових коштів, валюти, валютної цінності, електронних грошей тощо [8, с. 29-38]. Різноманітність точок зору наводить на думку, що в обліку криптовалюти слід розглядати, в залежності від призначення. А. Стовпова виділяє наступні групи криптовалют: вони можуть бути загальноцільовим засобом платежу (купуємо будь-що, - принаймні так задекларовано); вони можуть бути вузькоцільовим засобом платежу (купуємо тільки певні послуги у певному середовищі, наприклад, веб-сайті); вони можуть використовуватися як засіб залучення капіталу (аналог електронної акції); вони можуть мати різні можливості щодо документування (Ethereum, наприклад) [9]. Тобто ця класифікація підтверджує думку фахівців відомої аудиторської компанії 3 «Big4», які вважать, що криптовалюти можуть бути визнані як: гроші, грошові еквіваленти або зарубіжна валюта; фінансові інструменти; товари; запаси; нематеріальні активи [5, с.53]. Інші автори криптовалюту інтерпретують як електронні гроші, власність, віртуальний товар, віртуальну валюту, приватний платіжний засіб [10]. Однак, Р. Бруханський та І. Спільник вважають, що у зв'язку з їх цифровою природою та неоднозначністю ознак, а також залежно від мети їх придбання та терміну очікуваного використання, можливість однозначного віднесення криптографічних об'єктів до певного виду активів (i не тільки у складі активу балансу, але й у його пасиві) у системі обліку є доволі складною методологічною проблемою. У багатьох випадках відповіддю на питання про віднесення певного активу до відповідної групи може бути і «так», i «ні», або «не зовсім» [11]. Проведений аналіз запропонованих методик обліку операцій $з$ криптовалютами, дозволив зробити наступні висновки. Вчені рекомендують обліковувати криптовалюту у складі: нематеріальних активів, фінансових інвестицій; товарів. Згуртовані рекомендації щодо обліку операцій 3 криптовалютами наведені в табл. 1.

Таблиия 1

Пропозиції щодо обліку операцій з криптовалютами

\begin{tabular}{|c|c|c|}
\hline \multirow[t]{2}{*}{ Зміст господарської операції } & \multicolumn{2}{|c|}{$\begin{array}{l}\text { Кореспонденція } \\
\text { рахунків }\end{array}$} \\
\hline & Дт & Кт \\
\hline 1 & 2 & 3 \\
\hline \multicolumn{3}{|l|}{ Пропозичія Ячик Т.В. [6] } \\
\hline $\begin{array}{l}\text { Відображено внесок до статутного капіталу у вигляді нематеріального } \\
\text { активу Біткоін-гаманця }\end{array}$ & 127 & 46 \\
\hline
\end{tabular}


Продовження таблиці 1

2

Відображено у бухгалтерському обліку згенеровану криптовалюту власними інформаційно-технічними засобами

Купівля криптовалюти Біткоін за електронні гроші

Пропозииії Петрук О.М. і Новак О.С. [5]

Відображено придбання криптовалюти (визначено собівартість фінансової інвестиції)

Відображено реалізацію криптовалюти

Списано собівартість реалізованої фінансової інвестиції

Облік 3 утримання криптовалюти як фінансової інвестиції:

Відображено придбання криптовалюти (визначено собівартість фінансової інвестиції)

Відображено реалізацію криптовалюти

Відображено дооцінку криптовалюти. Результат дооцінки відображено в капіталі

Списано собівартість реалізованої фінансової інвестиції

Відображено отримання грошових коштів

Пропозичія Слободенюк О. [12]

Амортизація основних засобів, задіяних у створенні нематеріального цифрового активу «Біткойн»

$\begin{array}{lllll}\text { Розрахунки } 3 \text { вітчизняними постачальниками, в } & \text { т.ч.: }\end{array}$ електроенергія, оренда приміщення, оплата Інтернет

Відображено ПДВ

Нарахована заробітна плата з відрахуваннями

Введено в експлуатацію (за актом НА-1)

Пропозииія Костюченко В.М., Малиновської А.М., Мамонової А.В. [10]

\begin{tabular}{|c|c|c|}
\hline Добування криптовалюти & 154 & $\begin{array}{l}685 \\
117 \\
661\end{array}$ \\
\hline Оприбуткування криптовалюти & $\begin{array}{c}126 \\
\text { «Утримувана } \\
\text { криптовалюта» }\end{array}$ & 154 \\
\hline $\begin{array}{l}\text { Втрата криптовалюти, заробленої шляхом майнінгу (хакерська } \\
\text { атака, злом серверу і т.д.) }\end{array}$ & 97 & 126 \\
\hline Придбання криптовалюти на біржі & 154,126 & 68 , \\
\hline Оплата придбаної криптовалюти & 68 & 30,31 \\
\hline $\begin{array}{l}\text { Отримання криптовалюти як винагороди за перегляд ролику в } \\
\text { Інтернеті }\end{array}$ & 154,126 & 685 \\
\hline
\end{tabular}


Закінчення таблиці 1

\begin{tabular}{|c|c|c|}
\hline 1 & 2 & 3 \\
\hline \multicolumn{3}{|l|}{ Обмін неподібними активами: } \\
\hline \multirow[t]{2}{*}{ Оприбуткування криптовалюти за ціною переданої криптовалюти } & $\begin{array}{l}377,97, \\
154,685\end{array}$ & $\begin{array}{l}74,126, \\
685,31, \\
30,377\end{array}$ \\
\hline & 126 & 154 \\
\hline \multicolumn{3}{|l|}{ Обмін подібними активами: } \\
\hline Оприбуткування криптовалюти & $\begin{array}{c}154, \\
377,97 \\
685,126\end{array}$ & $\begin{array}{c}685,126, \\
126,377, \\
154\end{array}$ \\
\hline Відображено отримані товари (роботи, послуги) за криптовалюту & 28 & 685 \\
\hline Погашення заборгованості криптовалютою & 685 & 126 \\
\hline Криптовалюта, що утримується для перепродажу & 286 & 126 \\
\hline \multicolumn{3}{|l|}{ Пропозииія Дерун І.А. та Склярук І.П. [13] } \\
\hline Придбання веб-гаманця для операцій із криптовалютами & $\begin{array}{l}154 \\
127\end{array}$ & $\begin{array}{c}31 \\
154\end{array}$ \\
\hline Придбання криптовалюти для купівлі реальних товарів чи послуг & 336 & 31 \\
\hline Придбання криптовалюти для спекулятивних цілей & 352 & 31 \\
\hline Підвищення ціни криптовалюти, яка міститься на веб-гаманці & 352 & 740 \\
\hline Зменшення ціни криптовалюти, яка міститься на веб-гаманці & 970 & 352 \\
\hline $\begin{array}{l}\text { Реалізація криптовалюти після різкого підвищення ціни на неї } \\
\text { (спекулятивний ефект): } \\
\text { - отримання доходу від суттєвого підвищення ціни н на } \\
\text { криптовалюту; } \\
\text { - списано вартості придбання криптовалюти; } \\
\text { - } \quad \text { нараховано дохід від реалізації криптовалюти; } \\
\text { - списано спекулятивну дооцінку вартості криптовалюти; } \\
\text { - } \quad \text { отримано кошти від продажу криптовалюти. }\end{array}$ & $\begin{array}{l}352 \\
971 \\
377 \\
377 \\
311\end{array}$ & $\begin{array}{l}740 \\
352 \\
741 \\
352 \\
352\end{array}$ \\
\hline Витрати майнінгу на створення власними силами криптовалюти & $\begin{array}{l}977 \\
641 \\
685\end{array}$ & $\begin{array}{c}685 \\
685 \\
31\end{array}$ \\
\hline $\begin{array}{l}\text { Відображення створення нового блокчейну та створення певної суми } \\
\text { криптовалюти (капіталізація витрат майнінгу) }\end{array}$ & 352 & 977 \\
\hline $\begin{array}{l}\text { Використання створеної власними } \\
\text { придбання товарів та послуг }\end{array}$ & 336 & 352 \\
\hline
\end{tabular}

Відображення операцій на рахунках дозволяє зробити висновок, що тільки Костюченко В.М., Малиновська А.М., Мамонова А.В. пропонують введення нового субрахунку 126 «Утримувана криптовалюта» до Плану рахунків, усі інші автори використовують вже відомі рахунки. В основному при розгляді операцій з обліку криптовалюти, мова йде про Bitcoin, оскільки саме цей вид криптовалют найпоширеніший в Україні.

Стрімка трансформація світової економіки спонукає до поглиблення досліджень у напрямку вивчення та застосування криптовалют, їх обліку, пошуку шляхів іiі адаптації до особливостей національної економіки. Відсутність методичної бази з обліку криптовалют зменшує перспективи їх 
стабільного використання в національній економіці. Облікові аспекти цього явища - це те, що створює безліч дискусій і протиріч. У нашій країні, як і у більшості цивілізованих країн, технології випереджають законодавство. Ураховуючи, що облік в Україні є регламентованим, легалізація криптовалют повинна починатись 3 розробки та впровадження нормативних актів, наприклад, окремого П(С)БО, який би чітко окреслив питання, пов'язані 3 оцінкою, витратами і т.ін., у виробників, продавців, користувачів криптовалют, оскільки, криптобізнес є сформованою індустрією. До моменту затвердження офіційних нормативних актів, підприємства можуть внести відповідну інформацію щодо обліку криповалют у Наказ про облікову політику. Зразу обумовимо, що немає заборони на операції з криптовалютами. Згідно зі ст. 42 Конституції України, кожен має право на підприємницьку діяльність, яка не заборонена законом. Листом Держстату від 05.10.2018 p. №14.4-09/435-18 рекомендовано класифікувати майнінг і реалізацію криптовалют за КВЕДом 64.19 «Інші види грошового посередництва», а торгівлю (обмін) криптовалютами - за КВЕДом 66.19 «Інша допоміжна діяльність у сфері фінансових послуг, крім страхування та пенсійного забезпечення» [14].

Документування - це та проблема, без вирішення якої, неможливо відображати криптовалюту на рахунках бухгалтерського обліку. Вважаємо, що документування операцій з криптовалютою слід відображати у бухгалтерських довідках.

Відсутність єдиного підходу до визначення економічної сутності криптовалют і приводить до досить різної інтерпретації методичних підходів до відображення їх у бухгалтерському обліку. Нами розглянуті ці підходи у попередньому питанні. Для роз'яснення цієї ситуації можна звернутись до документів, прийнятих Радою МСБО. У березні 2019 року Комітет 3 інтерпретації міжнародної фінансової звітності (IFRIC) прийняв документ Holdings of Cryptocurrencies. Згідно 3 документом: криптовалюта - це цифрова або віртуальна валюта, яка записана в розподіленій книзі та використовує криптографію для безпеки, не видається юрисдикційним органом або іншою стороною; утримання криптовалюти не призводить до укладення договору між власником та іншою стороною [15]. Комітет зауважив, що криптовалюта, яка утримується, відповідає визначенню нематеріального активу в МСБО 38 на тих підставах, що: він може бути відокремлений від власника і проданий або переданий окремо; він не надає власнику права на отримання фіксованої або визначеної кількості одиниць валюти. Комітет дійшов висновку, що МСБО 2 «Запаси» застосовується до криптовалют, коли вони утримуються для продажу у звичайному бізнесі. Якщо МСБО 2 не застосовується, суб'єкт господарювання застосовує МСБО 38 до криптовалют, що утримуються [7].

Оскільки, українські підприємства працюють за правилами, які диктує європейський ринок та сучасні економічні відносини, то слушно взяти до уваги розробки Комітету з інтерпретації міжнародної фінансової звітності. Якщо синхронізувати вище сказане і український План рахунків, то для обліку криптовалют, можна використовувати рахунок 12 «Наматеріальні активи», 
доречним буде відкриття субрахунку 126 «Утримувана криптовалюта», який запропоновано Костюченко В.М., Малиновською А.М., Мамоновою А.В. При продажу криптовалют, на наш погляд, слід використати рахунок 28 «Товари», відкривши до нього субрахунок 287 «Криптовалюти для продажу», який буде мати ознаки активного рахунку (табл. 2). Аналітичний облік доцільно вести за напрямами надходження та використання криптовалюти в результаті господарських операцій, а також за видами криптовалют.

Табличя 2

Облік операцій 3 продажу криптовалют

\begin{tabular}{|l|c|c|}
\hline \multicolumn{1}{|c|}{ Зміст господарської операції } & Дебет & Кредит \\
\hline Криптовалюта, уо утримується для перепродажу & 287 & 127 \\
\hline Продано криптовалюту & 377 & 702 \\
\hline Нараховано податкові зобов’язання з ПдВ & 702 & 641 \\
\hline Списано собівартість реалізованої криптовалюти & 977 & 287 \\
\hline $\begin{array}{l}\text { Віднесено на фінансовий результат дохід від реалізації } \\
\text { товарів }\end{array}$ & 702 & 793 \\
\hline $\begin{array}{l}\text { Віднесено на фінансовий результат собівартість реалізованих } \\
\text { товарів }\end{array}$ & 793 & 977 \\
\hline \begin{tabular}{l} 
Отримано кошти від покупця \\
\hline
\end{tabular} & $311(312)$ & 377 \\
\hline
\end{tabular}

Розвиток цифрових технологій і віртуальних ринків виявив неготовність облікової науки та практики до викликів криптоіндустрії, тому до сьогодні існує спектр суттєвих аспектів, які потребують подальших досліджень.

Висновки i перспективи подальших досліджень. Узагальнивши пропозиції науковців щодо обліку криптовалют, ми прийшли до висновку щодо необхідності використання рахунку 12 «Наматеріальні активи» з відкриттям до нього субрахунку 126 «Утримувана криптовалюта». Облік операцій 3 продажу криптовалют, на наш погляд, слід залучати рахунок 28 «Товари», відкривши до нього субрахунок 287 «Криптовалюти для продажу», який буде мати ознаки активного рахунку. Аналітичний облік доцільно вести за напрямами надходження та використання криптовалюти в результаті господарських операцій, а також за видами криптовалют. У подальшому, при дослідженні обліку криптовалют, слід звернути увагу на методи їх оцінки.

\section{Перелік посилань}

1. Bitcoin developer chats about regulation, open source, and the elusive Satoshi Nakamoto, PCWorld, 26-05-2013: сайт URL: https://www.pcworld.com/article/2039184 (дата звернення: 11.01.2020).

2. Ярова К. Криптовалюта: визначення правового статусу в Україні: сайт URL: file:///C:/Users/user/Downloads/molv_2017_10_253.pdf (дата звернення: 11.01.2020).

3. Волосович С. Державне регулювання ринку криптовалют: зарубіжний досвід: сайт URL: file:///C:/Users/user/Downloads/uazt_2018_1_10.pdf (дата звернення: 11.01.2020).

4. Шевченко Л. Методика обліку криптовалют в умовах нестабільності діючого законодавства: сайт

URL: 

11.01.2020).

5. Петрук О. М., Новак О.С. Сутність криптовалюти як методологічна передумова її відображення. Економічні науки. 2017. Вип. 4 (82). С. 48-55.

6. Яцик Т. В. Методика фінансового обліку криптовалюти як особливого виду електронних грошей. Молодий вчений. 2017. № 2. С. 349-354.

7. Загнітко О. Біткоін: налаштувати не можна забороняти. Kyiv School of Economics: сайт URL : http://www.kse.org.ua/en/about/kse-news/?news id=2096 (дата звернення: 22.12.2019).

8. Безверхий К., Кувшинова А. Криптовалюта: гроші чи мильна бульбашка? Бухгалтерський облік і аудит. 2018. № 1. С. 29-38.

9. Стовпова А. С. Криптоактиви як об'єкт бухгалтерського обліку: сайт URL: http://www.economy.in.ua/pdf/8_2018/18.pdf (дата звернення: 10.11.2019).

10. Костюченко В. М., Малиновська А. М., Мамонова А. В. Бухгалтерський облік криптовалют: сайт URL: http://www.marketinfr.od.ua/journals/2019/33_2019_ukr/52.pdf (дата звернення: 24.12.2019).

11. Бруханський P. Ф., Спільник I. В. Криптоактиви у системі бухгалтерського обліку та звітності: сайт URL: https://www.problecon.com/export_pdf/problems-of-economy-2019-2_0-pages145_156.pdf (дата звернення: 24.12.2019).

12. Слободенюк О. Як вести облік біткойнів у бухгалтерії: приклад реального бізнесу: сайт URL: https://ain.ua/2018/09/05/bitkoiny-v-buxgalterii/ (дата звернення: 20.12.2019).

13. Дерун I. А., Склярук I. П. Онтологічні аспекти сутності криптовалюти та іiі відображення в обліку: сайт URL: https://eprints.oa.edu.ua/7658/1/28.pdf (дата звернення: 20.12.2019).

14. Загрядська M. Криптовалюти в Україні: сайт URL: http://yurgazeta.com/publications/practice/podatkova-praktika/kriptovalyuti-v-ukrayini.html (дата звернення: 24.12.2019).

15. The March 2019 IFRS Interpretations Committee Update. IFRS: сайт URL :https://www.ifrs.org/news-andevents/2019/03/march-2019-ifric-update-published/ (дата звернення: 21.12.2019).

\section{References}

1. Bitcoin developer chats about regulation, open source, and the elusive Satoshi Nakamoto, PCWorld, 26-05-2013, available at : https://www.pcworld.com/article/2039184 (last accessed 11.01.2020).

2. Yarov, K. Cryptocurrency: Determining Legal Status in Ukraine [Kryptovalyuta: vyznachennya pravovoho statusu v Ukrayini], available at : file: /// C: /Users/user/Downloads/molv_2017_10_253.pdf (last accessed 11.01.2020).

3. Volosovich, S. State Regulation of the Cryptocurrency Market: Foreign Experience [Derzhavne rehulyuvannya rynku kryptovalyut: zarubizhnyy dosvid], available at : file:///C:/Users/user/Downloads/uazt_2018_1_10.pdf (last accessed 11.01.2020). 
4. Shevchenko, L. Methods of accounting for cryptocurrencies in the conditions of instability of current legislation [Metodyka obliku kryptovalyut $\mathrm{v}$ umovakh nestabil'nosti diyuchoho zakonodavstva], available at : http://www.economy.nayka.com.ua/pdf/1_2020/158.pdf (last accessed 11.01.2020).

5. Petruk, O. M., Novice, O. S. (2017), The essence of cryptocurrency as a methodological premise for its reflection [Sutnist' kryptovalyuty yak metodolohichna peredumova yiyi vidobrazhennya], Economic sciences, No 4 (82), P. 48-55.

6. Yatsik, T. V. (2017), Methods of financial accounting for cryptocurrency as a special kind of electronic money [Metodyka finansovoho obliku kryptovalyuty yak osoblyvoho vydu elektronnykh hroshey], Young scientist, No 2, P. 349-354.

7. Zagnitko, O. Bitcoin: Customization cannot be prohibited [Bitkoin: nalashtuvaty ne mozhna zaboronyaty], Kyiv School of Economics, available at : http://www.kse.org.ua/en/about/kse-news/?news id $=2096$ (last accessed 22.12.2019).

8. Bezverkhiy, K., Kuvshinova, A. (2018), Cryptocurrency: Money or a Bubble? [Kryptovalyuta: hroshi chy myl'na bul'bashka?], Accounting and Auditing, No 1, P. 29-38.

9. Stovpova, A. S. Crypto-assets as an Object of Accounting [Kryptoaktyvy yak ob'yekt bukhhalters'koho obliku], available http://www.economy.in.ua/pdf/8_2018/18.pdf (last accessed 10.11.2019).

10. Kostyuchenko, V. M, Malinovskaya, A. M, Mamonova, A. V. Cryptocurrency Accounting [Bukhhalters'kyy oblik kryptovalyut], available at : http://www.market-infr.od.ua/journals/2019/33_2019_eng/52.pdf (last accessed 24.12.2019).

11. Brukhansky, R. F., Spilnyk, I. V. Crypto-assets in accounting and reporting system [Kryptoaktyvy u systemi bukhhalters'koho obliku ta zvitnosti], available at : https://www.problecon.com/export_pdf/problems-of-economy-2019-2_0-pages145_156.pdf (last accessed 24.12.2019).

12. Slobodeniuk, O. How to Keep Bitcoin Accounting in Accountancy: An Example of Real Business [Yak vesty oblik bitkoyniv u bukhhalteriyi: pryklad real'noho biznesu], available at : https://ain.ua/2018/09/05/bitkoiny-v-buxgalterii/ (last accessed 20.12.2019).

13. Derun, I. A., Sklyaruk, I. P. Ontological aspects of the essence of cryptocurrency and its reflection in accounting [Ontolohichni aspekty sutnosti kryptovalyuty ta yiyi vidobrazhennya $\mathrm{v}$ obliku], available at : https://eprints.oa.edu.ua/7658/1/28.pdf (last accessed 20.12.2019).

14. Zagryadska, M. Cryptocurrencies in Ukraine [Kryptovalyuty v Ukrayini], available at : http://yur-gazeta.com/publications/practice/podatkovapraktika/kriptovalyuti-v-ukrayini.html (last accessed 24.12.2019).

15. The March 2019 IFRS Interpretations Committee Update. IFRS, available at : https://www.ifrs.org/news-andevents/2019/03/march-2019-ifric-updatepublished/ (last accessed 21.12.2019). 


\section{РЕФЕРАТИ РЕФЕРАТЫ ABSTRACTS}

\section{УДК 657.01; JEL Classification: M41}

КОВАЛЬОВА Т.В. СТАНОВЛЕННЯ ТА ШЛЯХИ УДОСКОНАЛЕННЯ ОБЛІКУ КРИПТОВАЛЮТ. Метою дослідження $є$ висвітлення процесу становлення обліку криптовалют та розробка практично значимих пропозицій його покращення. Методика дослідження: для досягнення поставленої мети у роботі були використані загальнонаукові i спеціальні методи і прийоми дослідження: теоретичного узагальнення, аналізу і синтезу; системного і комплексного підходу; абстрактно-логічний. Результати дослідження: результатом наукового дослідження $є$ теоретичне узагальнення і розробка шляхів удосконалення обліку криптовалют. Поява нових фінансових інструментів стала можливою завдяки поширенню ITтехнологій та загальній комп'ютеризації. Ці інструменти впливають на фінансові системи окремих країн, на розвиток економіки, сприяють появі нових фінансових інститутів та форм взаємодії між людьми. Такою фінансовою новацією стала криптовалюта. Поява нового продукту на ринку інноваційних технологій зумовило появу і потенційного об’єкту обліку - криптовалют. Бухгалтерський облік, який формує повну i достовірну інформацію про діяльність підприємства, не може стояти осторонь від цього об'єкту. Дослідження точок зору науковців та бухгалтерської спільноти дали можливість нам висловити свою точку зору на це питання і запропонувати варіанти вирішення питань щодо організації обліку криптовалют, зокрема, в частині її продажу. Наукова новизна: полягає в комплексному дослідженні проблем, пов'язаних з обліком криптовалют. Запропоновано ввести в дію нові субрахунки, які забезпечать можливість відображати в обліку криптовалюти за відсутності нормативної бази з цього питання. Практична значущість полягає в тому, що, за відсутності нормативного врегулювання питань обліку криптовалют, указані у роботі пропозиції дадуть змогу практикам покращити стан їх обліку.

Ключові слова: облік; криптовалюта; нематеріальні активи; електронні гроші; рахунок.

\section{УДК 657.01; JEL Classification: M41}

КОВАЛЕВА Т.В. СТАНОВЛЕНИЕ И УСОВЕРШЕНСТВОВАНИЯ УЧЕТА КРИПТОВАЛЮТ. ЦеЛЬЮ исследования являются освещения процесса становления учета криптовалют и разработка практически значимых предложений его улучшения. Методика исследования: для достижения поставленной цели в работе были использованные общенаучные и специальные методы и приемы исследования: теоретического обобщения, анализа и синтеза; системного и комплексного подхода; абстрактно-логический. Результаты исследования: результатом научного исследования является теоретическое обобщение и разработка путей усовершенствования учета криптовалют. Появление новых финансовых инструментов стало возможной благодаря распространению IT-технологий и 
общей компьютеризации. Эти инструменты влияют на финансовые системы отдельных стран, на развитие экономики, оказывают содействие появлению новых финансовых институтов и форм взаимодействия между людьми. Такой финансовой новацией стала криптовалюта. Появление нового продукта на рынке инновационных технологий обусловило появление и потенциального объекта учета - криптовалюты. Бухгалтерский учет, который формирует полную и достоверную информацию о деятельности предприятия, не может стоять в стороне от этого объекту. Исследование точек зрения научный работников и бухгалтерского сообщества дали возможность нам высказать свою точку зрения на этот вопрос и предложить варианты решения вопросов относительно организации учета криптовалют, в частности, при ее продажи. Научная новизна: заключается в комплексном исследовании проблем, связанных с учетом криптовалют. Предложено ввести в действие новые субсчеты, которые обеспечат возможность отображать в учете криптовалюты при отсутствии нормативной базы по этому вопросу. Практическая значимость заключается в том, что, при отсутствии нормативного урегулирования вопросов учета криптовалют, указанные в работе предложения дадут возможность практикам улучшить состояние их учета.

Ключевые слова: учет; криптовалюта; нематериальные активы; электронные деньги; счет.

\section{UDC 657.01; JEL Classification: M41}

KOVALOVA T., V. FORMATION AND WAYS TO IMPROVE THE ACCOUNTING OF CRYPTO CURRENCIES. The aim of the study is to cover the process of formation of accounting of crypto currencies and development of practically significant suggestions for its improvement. Methods of research: to achieve the goal in the work were used general scientific and special methods and techniques of research: theoretical generalization, analysis and synthesis; system and complex approach; abstractly logical. Research results: the result of scientific research is theoretical generalization and development of ways to improve accounting of crypto currencies. The appearance of new financial instruments became possible due to the spread of IT technologies and general computerization. These tools influence the financial systems of certain countries, the development of the economy, contribute to the emergence of new financial institutions and forms of interaction between people. Such financial innovation has become a crypto currency. Appearance of a new product on the market of innovative technologies has caused the appearance of a potential object of accounting - crypto currencies. Accounting, which forms complete and reliable information about the activity of the enterprise, can not stand aside from this object. Researches of points of view of scientists and accounting community gave us an opportunity to express our point of view on this issue and to offer variants of solving questions concerning organization of crypto currency accounting, in particular, its sale. Scientific novelty: lies in the comprehensive study of problems related to the accounting of crypto currency. It is proposed to introduce new sub-accounts that will make it possible to display crypto currency accounting in 
the absence of a regulatory framework on this issue. Practical significance lies in the fact that, in the absence of a regulatory framework for crypto currency accounting, the proposals will enable practitioners to improve their status of accounting.

Keywords: accounting; crypto currency; intangible assets; electronic money.

\section{Відомості про авторів /Сведения об авторах / About the Authors}

Ковальова Тетяна Володимирівна - кандидат економічних наук, доцент, Харківський національний автомобільно-дорожній університет, доцент кафедри обліку, оподаткування та міжнародних економічних відносин; м. Харків,Україна; ORCID: https://orcid.org/0000-0003-1250-2019; e-mail: kovaleva64@ukr.net.

Ковалева Татьяна Владимировна - кандидат экономических наук, доцент, Харьковский национальный автомобильно-дорожный университет, доцент кафедры учета, налогообложение и международных экономических отношений.

Kovalova Tetiana Volodimipovna - Candidate of Sciences (Economics), Kharkov National Automobile and Highway University, Associate Professor at the Department of account, taxation and international economic relations, Kharkiv, Ukraine. 